\title{
Elderly residents in the community: gaining knowledge to support a rehabilitation nursing program
}

\author{
Idosos residentes na comunidade: conhecer para sustentar um programa de enfermagem de reabilitação
}

Ancianos residentes en la comunidad: conocer para defender un programa de enfermería de rehabilitación

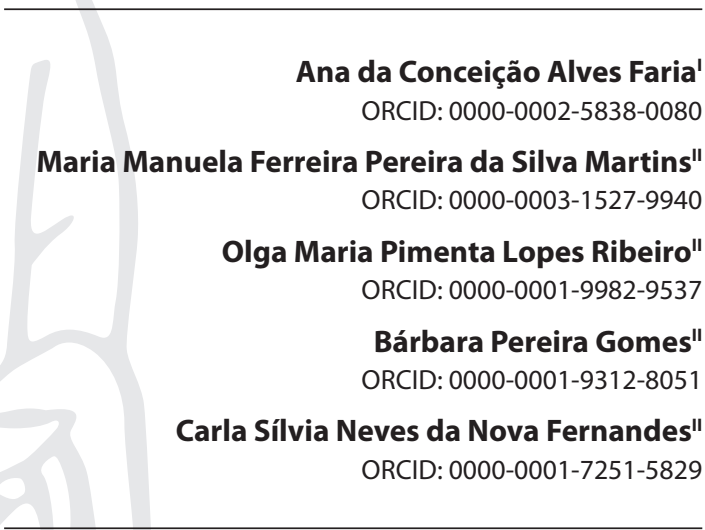

'Universidade do Porto, Instituto de Ciências Biomédicas Abel Salazar. Porto, Portugal.

"Escola Superior de Enfermagem do Porto. Porto, Portugal

How to cite this article: Faria ACA, Martins MMFPS, Ribeiro OMPL, Gomes BP, Fernandes CSNN. Elderly residents in the community: gaining knowledge to support a rehabilitation nursing program. Rev Bras Enferm. 2020;73(Suppl 3):e20200194. doi: http://dx.doi.org/10.1590/0034-7167-2020-0194

Corresponding author:

Ana da Conceição Alves Faria

E-mail: acafaria@arsnorte.min-saude.pt

EDITOR IN CHIEF: Antonio José de Almeida Filho ASSOCIATE EDITOR: Álvaro Sousa

Submission: 05-04-2020

Approval: 08-25-2020

\section{ABSTRACT}

Objective: To analyze the socio-demographic and health conditions of the elderly living in the community and describe the pillars for the design of a rehabilitation nursing program in the community. Methods: Descriptive, cross-sectional study, with participation of 48 elderly selected by convenience sampling. Data collection took place between September 2018 and July 2019, in a health unit in northern Portugal, using a form. Results: All the elderly have pathological processes and overweight. Most of them are sedentary, have feelings of loneliness and inappropriate relational behaviors. In the last six months, 25\% have fallen at least once, with notable changes in balance, lifestyles and perceived health status. Conclusion: The need for rehabilitation nurses to design and implement active aging programs that ensure individual accompaniment of the elderly by valuing lifestyles, balance training and promotion of social participation was highlighted.

Descriptors: Elderly; Rehabilitation Nursing; Rehabilitation; Health Promotion; Life Style.

\section{RESUMO}

Objetivo: Analisar as condições sociodemográficas e de saúde dos idosos residentes na comunidade e descrever os pilares para a concepção de um programa de enfermagem de reabilitação na comunidade. Métodos: Estudo descritivo, transversal, com participação de 48 idosos selecionados por amostragem de conveniência. A coleta de dados realizou-se entre setembro de 2018 e julho de 2019, numa unidade de saúde do norte de Portugal, usando um formulário. Resultados: Todos os idosos têm processos patológicos e excesso de peso. Majoritariamente são sedentários, apresentam sentimentos de solidão e comportamentos relacionais inapropriados. Nos últimos seis meses, $25 \%$ caíram pelo menos uma vez, tendo sido notórias alterações no equilíbrio, estilos de vida e percepção do estado de saúde. Conclusão: Evidenciou-se a necessidade de os enfermeiros de reabilitação conceberem e implementarem programas de envelhecimento ativo que garantam acompanhamento individual dos idosos valorizando estilos de vida, treino de equilíbrio e promoção da participação social.

Descritores: Descritores: Idoso; Enfermagem em Reabilitação; Reabilitação; Promoção da Saúde; Estilo de Vida.

\section{RESUMEN}

Objetivo: Analizar las condiciones sociodemográficas y de salud de ancianos residentes en la comunidad y describir los pilares para la concepción de un programa de enfermería de rehabilitación en la comunidad. Métodos: Estudio descriptivo, transversal, con participación de 48 ancianos seleccionados por muestreo de conveniencia. La recogida de datos se realizó entre septiembre de 2018 y julio de 2019 , en unidad de salud del norte de Portugal, usando un formulario. Resultados: Todos los ancianos tienen procesos patológicos y sobrepeso. Mayoritariamente son sedentarios, sienten soledad y comportamientos relacionales inapropiados. En los últimos seis meses, $25 \%$ cayeron por lo menos una vez, siendo notorias alteraciones en el equilibrio, estilos de vida y percepción en la salud. Conclusión: Se evidenció la necesidad de los enfermeros de rehabilitación concebir e implementar programas de envejecimiento activo que garantizan acompañamiento individual de ancianos valorizando estilos de vida, ejercicios de equilibrio y promoción de la participación social.

Descriptores: Anciano; Enfermería en Rehabilitación; Rehabilitación; Promoción de la Salud; Estilo de Vida. 


\section{INTRODUCTION}

Rehabilitation nurses providing care in the community are faced with the reality of an aging population, which, in addition to the pathologies that arise in the course of life, present problems associated with the aging process. The population over 60 is growing at a rate of about $3 \%$ per year. In 2017, it was estimated that 962 million people worldwide were 60 years or older, representing $13 \%$ of the global population ${ }^{(1)}$. The European context, particularly Portugal, is no exception. Currently, the life expectancy of the Portuguese is more than 80 years old, and about one million elderly people are over 75 years old ${ }^{(2)}$.

The improvement of living conditions, access to health care and the advances in medicine with more innovative therapies and medicines and the decrease in the prevalence of some diseases have contributed to prolonging people's lives. However, along with the increase in life expectancy, there is also a significant increase in chronic, degenerative and multi-morbid diseases, with implications for the functional and cognitive capacity and quality of life of older people ${ }^{(2)}$, and this makes the assistance at this age by rehabilitation nurses distinguish itself in two pillars: one focusing on the most frequent and common disease processes; and the other on the promotion of healthy lifestyles, welfare promoters and active aging.

Today we already have evidence that Portugal is one of the countries where you live in worse health for more years, and lifestyles and health behaviors continue to be the main risk factors for the loss of years of healthy life. In 2016, inadequate nutrition, alcohol abuse, smoking and sedentary lifestyle were among the main risk factors for the loss of years of healthy life in Portugal, and an important part of this disease burden is related to the mortality caused by them ${ }^{(2)}$.

Health conditions are determinant in the aging process, however it is also influenced by the physical environment, family, community and social support network, as well as by the economic and cultural conditions, and health professionals should be attentive to all these conditions in order to be facilitators of a healthy aging ${ }^{(1,3)}$. In the literature, models and research tools are available that evaluate the lifestyles that promote healthy aging. According to Nola Pender's Health Promotion model, the main components of a lifestyle that promotes healthy aging are: physical activity; adequate nutrition; health responsibility; interpersonal relationships; spiritual growth; and stress management ${ }^{(4)}$. The Individual Lifestyle Profile tool considers five essential factors for positive aging: physical activity, nutrition, preventive behavior, level of stress management and social relationship ${ }^{(5)}$.

In Portugal, the Directorate General for Health (DGS), in accordance with the guidelines of the World Health Organization (WHO) and the European Commission (EC), recognizes the importance of all health and social programs that contribute to the creation of safe environments and conditions that allow for the monitoring of the elderly(6).

Promoting active aging and social participation of the elderly is a challenge for health professionals, highlighting the role of the rehabilitation nurse, according to his skills profile, in promoting healthy lifestyles, health education, disease prevention, management of comorbidity processes and support in situations of vulnerability and activity limitation ${ }^{(7)}$. The rehabilitation nurse not only promotes health literacy, but also motivates adherence to health-promoting behaviors, seeks to understand the barriers that hinder access to these behaviors, thus favoring their inclusion, cooperates with community structures in order to promote a safe environment, as well as seeks to understand self-efficacy for action, enhancing the functional capacity and social integration of older people.

According to the literature review of the last ten years, the areas of nursing intervention in active aging and health promotion programs are: the promotion of physical exercise ${ }^{(8-17)}$, fall prevention $^{(18)}$, cognitive stimulation ${ }^{(8-9,13)}$, teaching about healthy eating habits ${ }^{(8-11,13-14,16-18)}$, the prevention and management of chronic diseases ${ }^{(8-10,13-14,17-18)}$, the management of the drug regimen $^{(8-10,13-14,17-18)}$ and the promotion of social interaction ${ }^{(8-11,17)}$.

The health gains reported with the implementation of active aging programs are: the improvement of functional capacity ${ }^{(8-16)}$, quality of life ${ }^{(14)}$, of social participation ${ }^{(17)}$ and health satisfaction ${ }^{(15)}$. Also described is the broadening of knowledge about healthy lifestyles ${ }^{(18)}$ and the decrease of acute episodes ${ }^{(12)}$, of the fragility index $^{(12-13)}$, of the fear of falling ${ }^{(15)}$ and the pain ${ }^{(15)}$.

It should be noted that the programs described in the literature, although implemented in different contexts, show important health gains, either through group activities or individual intervention in the elderly home. Home based programs, besides serving the individuality of the person and promoting healthy behaviors diminish feelings of loneliness and social isolation, favoring inclusion.

Given the relevance of implementing these programs in an increasingly aging population and in order to sustain a rehabilitation nursing program in the community not only in the evidence of the literature described above, but also in the real health and social needs of older people, a group of researchers sought to understand the aging process from the perspective of older people and to develop a program in that community. This study is part of a broader research entitled "PT4ageing: Personal Trainer for the health management of older people".

\section{OBJECTIVE}

To analyze the socio-demographic and health conditions of the elderly living in the community and describe the pillars for the design of a rehabilitation nursing program in the community.

\section{METHODS}

\section{Ethical aspects}

The development of this research met the ethical and legal precepts in all phases, as recommended by the National and International Standards of Ethics for conducting research involving human beings. This study was approved by the Ethics Committee of the Regional Health Administration of Northern Portugal in January 2018. The participants were informed about the objectives and purpose of the study and signed the informed consent form, guaranteeing confidentiality and anonymity in the use of the information collected. 


\section{Design, study site and period}

This is a descriptive, exploratory, cross-sectional study, guided by the Strengthening the Reporting of Observational Studies in Epidemiology (STROBE) tool, conducted in an urban health unit in northern Portugal, from September 2018 to July 2019. The collection of data using a form was carried out in a private environment in the referred health unit, where the investigator and the participant had privacy for the application of the form.

\section{Population or sample: inclusion and exclusion criteria}

The studied population was people over 65 years old residing at home, and the sampling technique used was the non-probabilistic of convenience, the sample consisting of 48 elderly people. The inclusion criteria were: to be an elderly person registered in a health unit in an urban region in the north of Portugal; to have gone to that health unit; according to the clinical judgment of the family nurses, to present therapeutic benefit in the implementation of the rehabilitation nursing program; and to accept to participate in the research project. All elderly people who did not have the cognitive capacity to respond to the form or showed inability to go to that health unit were excluded. In order to check the cognitive capacity, we evaluated people in the following areas: orientation; memory; concrete thinking; availability; and volition.

\section{Study protocol}

The study protocol comprised three phases: 1) selection of the elderly participants; 2 ) data collection with application of a form; and 3) design of a community-based rehabilitation nursing program based on the models described in the literature and the health needs identified in the elderly under study.

The selection of the elderly participants was made through inclusion criteria in the study. After the selection, the elderly were invited to participate in the study and the dates of data collection in the referred health unit were marked, according to the availability of the researchers and the elderly.

Based on the literature review, it was found that with aging, several changes in the health conditions of the elderly occur and the adoption of negative lifestyles, associated with changes in the balance that occur with advancing age: all this causes their isolation and loneliness. Thus, in order to evaluate these variables, researchers built a four-part form: sociodemographic characteristics (gender, age, marital status, number of household members, number of children, level of education, source of income); health conditions (perception of health status, knowledge of pathological processes, perception of symptoms, drug regimen, weight, height, record of falls and perception of risk of falling, static and dynamic balance and number of hours of sleep), lifestyles (food, physical activity, preventive behavior, relational behavior and stress control) and perception of feelings of loneliness.

The Tinetti Index, the Individual Lifestyle Profile and the Loneliness Scale instrument of the University of California at Los Angeles (UCLA) were selected to evaluate the variables "static and dynamic balance", "lifestyle" and "Ioneliness ${ }^{(5,19-20)}$.

\section{Analysis of results and statistics}

The data was analyzed using the Statistical Package for the Social Sciences (SPSS) software, version 22.0, and descriptive and analytical statistics were used by calculating absolute $(\mathrm{N})$, relative (\%) frequencies; measures of central tendency (mean and median); measures of dispersion (minimum, maximum and standard deviation); and Mann-Whitney test. For data analysis, the value of $p<0.05$ was adopted as statistically significant. It was observed that the scales adopted for the form, in the sample under study, had a Cronbach's alpha between 0.7 and 0.9, which certifies the internal consistency of the instrument.

\section{RESULTS}

In the study, 48 elderly people participated, predominantly female (66.67\%), marital status/defacto union (56.25\%), 4th year of schooling $(43.8 \%)$, with two family members $(37.5 \%)$, with two children (41.3\%) and with retirement as a source of income (87.49\%). The age of participants varied between 65 and 90 years ( mean $=75$; standard deviation $=6.8$ ), with $77.08 \%$ in the third age (between 65 and 80 years) and $22.92 \%$ in the fourth age (between 81 and 90 years), according to Table 1.

Table 1 - Sociodemographic data of the elderly ( $N=48)$, Porto, Portugal, 2019

\begin{tabular}{lcc}
\hline Variables & Frequency & Percentage \\
\hline Gender & & \\
$\quad$ Female & 32 & 66.67 \\
Male & 16 & 33.33 \\
Age & & \\
$65-80$ & 37 & 77.0 \\
$81-90$ & 11 & 22.92 \\
Marital status & & \\
Married/consensual union & 27 & 56.25 \\
Widow/er & 15 & 31.25 \\
Divorced & 4 & 8.33 \\
Single & 2 & 4.17 \\
Source of income & & \\
$\quad$ Reform & 42 & 87.49 \\
Work & 2 & 4.17 \\
Social insertion income & 2 & 4.17 \\
Other & 2 & 4.17 \\
No. of household members & & \\
$\quad 0-1$ & 18 & 37.50 \\
$2-4$ & 29 & 60.42 \\
$\geq 5$ & 1 & 2.08 \\
Education (in full years) & & \\
$\quad \leq 9$ & 45 & 93.75 \\
$>9$ & 3 & 6.25 \\
\hline
\end{tabular}

Regarding health perception, $50 \%$ considered it acceptable; $37.4 \%$, good, and the same percentage considered it bad, very good and excellent (4.2\% each). Regarding the health condition/ disease, the following pathological processes are highlighted: cardiovascular diseases (76.6\%), endocrine diseases (56.8\%), musculoskeletal diseases (45.7\%), depression (16.3\%), respiratory diseases (14.3\%) and cerebrovascular diseases (9.3\%). Regarding the symptoms, the following are highlighted: musculoskeletal pain $(56.5 \%)$, decreased vision $(55.6 \%)$, difficulty in walking (32.6\%), constant imbalance and feelings of sadness (22.2\% each), 
urine loss (17.8\%) and memory changes (13.3\%). All the elderly take medication, and only one did not know how to mention the medication. Regarding the pharmacological groups, the oral antidiabetics (57.1\%), analgesics (26.3\%), antidepressants (25\%), anti-inflammatory (24.3\%), insulin (16.2\%) and sedatives (13.9\%) prevailed.

Regarding equilibrium, evaluated using the Tinetti Index, a mean score of 26 was confirmed, with a minimum of 16 , a maximum of 28 and a standard deviation of 2.8. In the last six months, $25 \%$ have fallen at least once and $33.3 \%$ are afraid of falling.

Regarding lifestyle, it was found that $54.2 \%$ of the elderly are not very active, $52.1 \%$ have inappropriate relational behaviors, $47.9 \%$ have difficulty in controlling stress, $7.8 \%$ do not have preventive behaviors and $37.5 \%$ have inadequate eating habits. All users were overweight, with repercussion on the Body Mass Index, which in all cases had values above 28 (mean $=44.4$; standard deviation $=6.8$ ).

Regarding the perception of loneliness, evaluated using the UCLA Scale, the mean was 27.4 , the median was 25 , the minimum was 18, the maximum 47, and the standard deviation was 9.3. The majority of the elderly (66.67\%) had a low level of loneliness; $20 \%$, moderate level of loneliness; and only $13.3 \%$ of the elderly are socially satisfied.

When analyzing the association between the different variables under study, using the Mann-Whitney test of independent samples, it was noted the existence of statistically significant differences $(p<0.05)$ between gender and perception of health status in relation to loneliness; between gender, perception of health status and perception of risk of falling in relation to total balance and between perception of health status in relation to lifestyles, as shown in Table 2.

Table 2 - Association of socio-demographic and health conditions of the elderly $(\mathrm{N}=48)$, Porto, Portugal, 2019

\begin{tabular}{lccc}
\hline Variables & $\begin{array}{c}\text { Loneliness } \\
\text { Significance }\end{array}$ & $\begin{array}{c}\text { Balance } \\
\text { Significance }\end{array}$ & $\begin{array}{c}\text { Life styles } \\
\text { Significance }\end{array}$ \\
\hline Gender & $0.009^{*}$ & $0.037^{*}$ & 0.233 \\
Ages & 0.900 & 0.413 & 0.352 \\
Maritaç status & 0.720 & 0.470 & 0.517 \\
Education & 0.772 & 0.886 & 0.502 \\
Sources of income & 0.261 & 0.556 & 0.445 \\
No. of household members & 0.107 & 0.793 & 0.103 \\
Perception of health status & $0.034^{*}$ & $0.031^{*}$ & $0.025^{*}$ \\
Falls in the last six months & 0.384 & 0.722 & 0.079 \\
Perception of risk of falling & 0.961 & $0.010^{*}$ & 0.923 \\
\hline
\end{tabular}

Note: *Statistically significant difference - Mann-Whitney test $(p<0,05)$.

When the distribution of loneliness was explored, it was detected that women, besides presenting a greater representation of loneliness, also show higher values of loneliness than men, being verified that, of the total of elderly that present loneliness, $74.4 \%$ are women and $25.6 \%$ are men. Regarding the perception of health, all people who consider their health as bad present moderate levels of loneliness and, although the distribution of loneliness is the same for the various sources of income, it should be noted that retired retirees have greater dispersion,

the midpoint value of the group being 24.35. When analyzing the household, we find that there are no significant differences between the numbers of elements $(p=0.107)$, however those with the highest scores are those living alone (a household element), the average point of this group being 28.66.

Regarding life styles, significant differences were detected regarding the perception of health $(p=0.025)$, and the totality of people who consider their health as bad have an average life style and the totality of people who perceive their health as excellent have a positive life style. People who show a negative lifestyle perceive their health as acceptable.

When analyzing the variable "equilibrium", significant differences were identified with respect to gender ( $p=0.037$ ), with higher values in men. While for women the mean total equilibrium was 25.4 and standard deviation 3.1, the mean total equilibrium for men was 27.1 and the standard deviation 1.4. Differences between balance and health perception were also detected ( $p$ $=0.031$ ), and the elderly with the best health perception are also those with higher scores in total balance. Similarly, the elderly who perceive no risk of falling are those who show the highest total equilibrium value.

From the findings, we can draw guidelines for the design and future implementation of a community-based rehabilitation nursing program based on the models described in the literature and the health needs identified in the elderly under study, as shown in Figure 1. This program is intended to begin in the elderly residence; and in a group, in a second phase, for the development of global programs that promote social interaction.

Individual intervention in the elderly residence - Once a week Frequency of 50 minutes

Physical Activity and
Training Session
5'- Welcoming
5'- Motivation and interaction
strategies
$15^{\prime}$ - Mobilization of body
segments
5 '- Postural control exercises
5 '- Static balance exercises
5'- Stretching exercises
$10^{\prime}$ - One of the following
strategies:
stress management
chronic disease management
management of eating habits
Initial evaluation
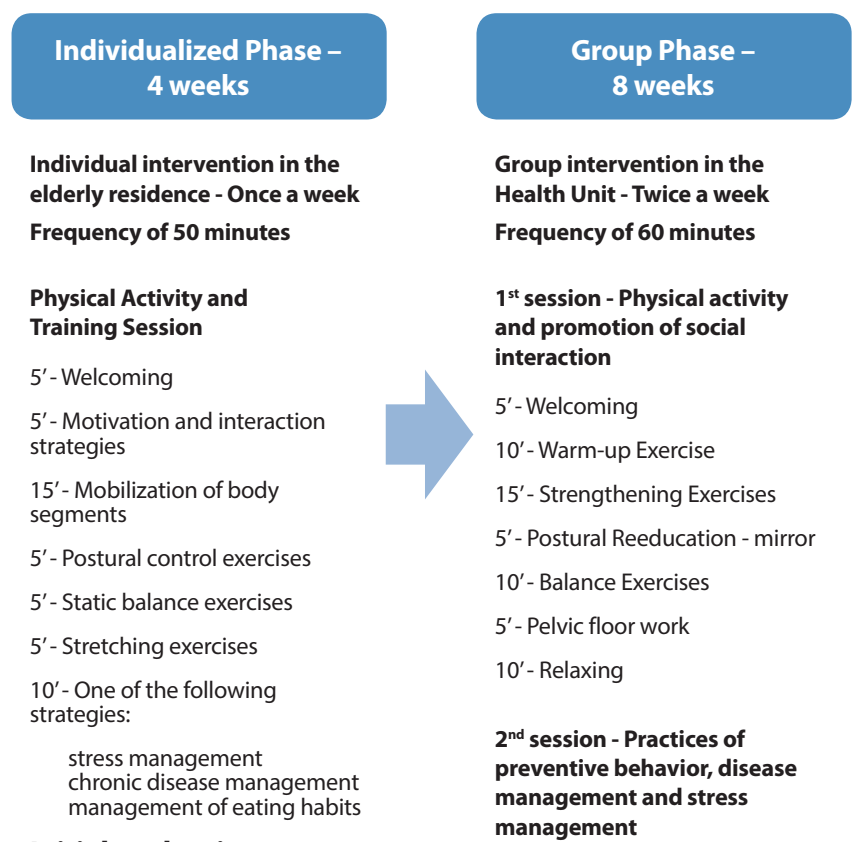

$10^{\prime}$ - Welcome techniques $40^{\prime}$ - Centrality in a theme $10^{\prime}$ - Summary of the theme

\section{Final evaluation}

Figure 1 - Pillars of the Community Rehabilitation Nursing Program 


\section{DISCUSSION}

In this study, the sample consists mostly of women (32 women and 16 men), and the average age of the participants was 75 years, similar to the national panorama, where the average life expectancy is 80.8 years, with women living on average 83.4 years, while men, on average up to 77.8 years $^{(21)}$. We found that the majority are married, and the household is composed of two elements, which is in line with data from INE (2019), which describe that, in Portugal, the average household size is 2.5 people, and in $12.4 \%$ of households, only people aged 65 or more reside ${ }^{(21)}$.

It was also seen that $31.3 \%$ of the elderly do not have any kind of schooling, and $43.8 \%$ have only the 1 st cycle. National studies describe that about $20 \%$ of the Portuguese elderly are illiterate, and $52.9 \%$ have the 1 st cycle as level of schooling ${ }^{(21)}$.

Regarding the source of income, most elderly people are retired $(87.49 \%)$, corroborating the data from studies according to which, on average, the Portuguese start receiving retirement at 63.8 years of age ${ }^{(21)}$.

In this study, it was also found that most elderly people consider their health condition acceptable. According to a study carried out in Portugal, $14.7 \%$ of the Portuguese between 65 and 74 years old and $7 \%$ of the Portuguese elderly aged 75 and over consider their health very good or good ${ }^{(22)}$. Another author states that, when the elderly define their health as good, they are not characterized as being free of disease, but are able to acquire strategies to act on the environment ${ }^{(23)}$

All the elderly reported a pathological condition, with cardiovascular disease being the most frequent pathology in this sample (76.6\%), followed by endocrine disease (56.8\%), musculoskeletal diseases (45.7\%), depression (16.3\%), respiratory diseases $(14.3 \%)$ and cerebrovascular diseases (9.3\%). In a study conducted in Portugal, it was confirmed that $71 \%$ of Portuguese aged 65 to 74 are hypertensive, and $23.8 \%$ have diabetes ${ }^{(2)}$. The WHO (2015) states that chronic non-communicable, circulatory, malignant, endocrine and respiratory diseases are the main causes of death in the world ${ }^{(24)}$, which reinforces the relevance of encouraging healthy lifestyles.

Regarding the symptoms, musculoskeletal pain (56.5\%), decreased vision (55.6\%), constant imbalance (22.2\%) and urine loss (17.8\%) predispose to difficulty in walking (32.6\%), episodes of falls (25\%) and fear of falling (33.3\%). Chronic pain is a common symptom among elderly people, affecting about $50 \%$ of the elderly living in the community. It is often associated with feelings of loneliness and depression, having a strong impact on the quality of life of the elderly ${ }^{(25)}$. Regarding falls and imbalances, several studies mention that older people present changes in balance, fear of falling, little confidence in their own balance, limiting their daily activities and isolating themselves from social participation. This situation leads to a vicious cycle in which sedentarism accentuates the functional loss and dependence on the daily activities of the elderly ${ }^{(26-27)}$. Postural instability, mobility, balance and continence problems, changes in sensory systems, cognitive impairment, polymedication and syncope syndrome are determinants for the occurrence of falls ${ }^{(28-29)}$. It was also found that men have higher balance scores than women, corroborating the studies that the osteoporosis more prevalent in women influences their loss of balance and falls above men $^{(30)}$.
We verified that the elderly present life styles that condition health and, when we analyze the five components of the life style scale, we verify that the worst results are associated to the behavior "physical activity" (54.2\%), followed by the relational behavior (52.1\%), stress control (47.9\%), preventive behavior (37.8\%) and, finally, the life style "feeding" (37.5\%). This data will confirm a recent study whose data shows that in Portugal $89 \%$ of men and $86 \%$ of women over 55 do not exercise ${ }^{(31)}$.

Studies report that, in the elderly population, problems in general health status, functionality and social interaction are aggravated by inactivity, which is due to the perception of barriers such as physical limitation, fear of falls, presence of pain, lack of disposition, lack of security and the feeling of not being able to perform the exercise because of never having done it before ${ }^{(3233)}$. Regarding eating habits, a recent study states that 8 out of 10 elderly people are overweight, which ratifies the data found in this study, in which $37.5 \%$ do not have adequate eating habits ${ }^{(2)}$. It was also detected that people with less positive lifestyles are the ones with the worst health perception, and this fact confirms that behaviors are determinants for people's health.

Regarding feelings of loneliness, $86.7 \%$ of the elderly were found to feel lonely, most describing slight levels of loneliness; and $20 \%$, moderate. It was also found that women show higher levels of loneliness, and this affects the perception of health, with the totality of elderly with moderate levels perceived as having poor health. Studies report that female gender, low socioeconomic status, living alone, inadequate social contact, scarce social resources and health problems influence the perception of feelings of loneliness, being a predictor of negative health outcomes. The structured family network, support and social participation work as protective factors in experiencing feelings of loneliness ${ }^{(34-35)}$.

Also, the personality of each elderly person and the way they have lived their lives so far can influence the perception of lonely feelings in the elderly, and those who cannot overcome these feelings are at risk of fragility and early institutionalization ${ }^{(36)}$. A recent study in primary health care reveals that about $91 \%$ of the elderly in the community describe feeling some degree of loneliness and a third describe severe levels $s^{(37)}$. According to the same authors, it is important to understand that loneliness in the elderly leads to greater somatization of their suffering, depressive symptoms, dynamic instability, sleep disturbances, falls and accidents, as well as lower adherence to medical therapy or overmedication ${ }^{(37)}$

Knowing that healthy life expectancy depends greatly on individual behaviors, promoting active aging should be a primary investment of rehabilitation nurses, thus encouraging the elderly to maintain a variety of activities after retirement, preserving social utility and preventing functional decline, loneliness and fragility that occur along with aging.

In this sense, in order to satisfy the health needs of the elderly people under study and to support the nursing program of rehabilitation to the elderly living in the community in the models described in the literature, guidelines for its design and implementation have been designed. The program aims to meet the individuality and difficulties of people, as well as promote healthy lifestyles, especially with regard to physical activity, social interaction, training for the adoption of preventive behaviors, 
disease management and stress management. The program aims to meet the individuality and difficulties of people, as well as promote healthy lifestyles, especially with regard to physical activity, social interaction, training for the adoption of preventive behaviors, disease management and stress management. The aim is to reduce feelings of loneliness and promote interaction through the rich exchange of experiences among the elderly, as several authors argue, given that an individualized intervention program, complemented with group intervention, promotes advantages both in functional capacity and social participation ${ }^{(16-17)}$.

\section{Study limitations}

The limitations of the study are that it is merely descriptive and exploratory and that the sample was of convenience and small size, preventing the generalization of the results.

\section{Contributions to the Nursing, Health or Public Policy area}

In recent years, there have been debates about the importance of active aging programs in order to delay the fragility and dependence that result from aging; however, such programs do not sustain their intervention in the real needs of this population.

In this study, it was confirmed that the elderly have unhealthy lifestyles, are sedentary and show static and walking balance. These conditions make the elderly take refuge at home, have low social participation and experience feelings of loneliness. Thus, it is vital to improve the health conditions of the elderly, promote accessibility, reduce vulnerability and loneliness, as well as focus on empowering and empowering the elderly to adopt healthy lifestyles and choose healthy environments.

\section{CONCLUSION}

From the attributes of the elderly participants in the study, a profile emerges that reflects the current socio-demographic and health changes. In fact, the predominance of cardiovascular, endocrine, musculoskeletal, psychiatric and respiratory diseases culminates in signs and symptoms that significantly deteriorate the quality of life of the elderly.

Their health conditions lead them to state that rehabilitation nurses have to value balance, life styles and social participation in nursing interventions in an individualized way, which is why, when groups for active aging programs are created, subgroups should be taken into account to intervene in aspects of higher risk. Rehabilitation nursing program strategies in the community should be appropriate to the level of understanding, schooling and specific needs of the participants.

Also, gender differences were found between male and female seniors in program interventions. Therefore, it is proposed that a Rehabilitation Nursing program be carried out in articulation with the rest of the health team and with the community partners.

The pillars for the design of a rehabilitation nursing program for the elderly in the community should address all the components of lifestyles, the static and dynamic balance, particularizing the development of gait and posture.

\section{REFERENCES}

1. World Health Organization (WHO). Global strategy and action plan ageing and health[Internet]. Switzerland: WHO; 2017 [cited 2020 Feb 02]. 46 p. Available from: https://www.who.int/ageing/WHO-GSAP-2017.pdf?ua=1.

2. Portugal. Ministério da Saúde. Retrato da Saúde 2018 [Internet]. Lisboa: Ministério da Saúde; 2018 [cited 2020 Jan 15]. 87 p. Available from: https://www.sns.gov.pt/wp-content/uploads/2018/04/RETRATO-DA-SAUDE_2018_compressed.pdf.

3. Bárrios MJ, Fernandes AA. A promoção do envelhecimento ativo ao nível local: análise de programas de intervenção autárquica. Rev Port Saúde Pública. 2014;32:188-96. doi:10.1016/j.rpsp.2014.09.002

4. Pender N, Murdaugh C, Parsons M. Health promotion in nursing practice. 7th ed. Upper Saddle River: Pearson/Prentice-Hall; 2015.

5. Nahas MV. Atividade física, saúde e qualidade de vida: conceitos e sugestões para um estilo de vida saudável. 6a edição. Londrina: Midiograf; 2013.

6. Direção Geral de Saúde (PT). Estratégia Nacional para o envelhecimento ativo e saudável 2017-2025 [Internet]. Lisboa; Ministério da Saúde; 2017 [cited 2020 Feb 15]. 52 p. Available from: https://www.sns.gov.pt/wp-content/uploads/2017/07/ENEAS.pdf.

7. Presidência do Conselho de Ministros (PT). Regulamento n. ${ }^{\circ}$ 125/2011. Regulamento das Competências Especificas do Enfermeiro Especialista em Enfermagem de Reabilitação[Internet]. Diário da República, Série II, n. 35/2011, 18 Fev 2011. [cited 2020 Feb 20]. Available from: https://dre.pt/home/-/dre/3477014/details/maximized

8. Behm L, Wilhelmson K, Falk K, Eklund K, Ziden L, Dahlin-Ivanoff S. Positive health outcomes following health-promoting and diseasepreventive interventions for independent very old persons: long-term results of the three-armed RCT Elderly Persons in the Risk Zone. Arch Gerontol Geriatr. 2014;58(3):376-83. doi: 10.1016/j.archger.2013.12.010

9. Dahlin-Ivanoff S, Gosman-Hedström G, Edberg A-K, Wilhelmson K, Eklund K, Duner A, et al. Elderly persons in the risk zone: design of a multidimensional, health-promoting, randomised three-armed controlled trial for "prefrail" people of 80+ years living at home. BMC Geriatr. 2010;10(1):27. doi: 10.1186/1471-2318-10-27

10. Gustafsson S, Eklund K, Wilhelmson K, Edberg A-K, Johansson B, Kronlöf GH, et al. Long-term outcome for adl following the healthpromoting rct-elderly persons in the risk zone. Gerontol. 2012;53(4):654-63. doi: 10.1093/geront/gns121

11. Haider S, Dorner TE, Luger E, Kapan A, Titze S, Lackinger C, et al. Impact of a home-based physical and nutritional intervention program conducted by lay-volunteers on handgrip strength in prefrail and frail older adults: a randomized control trial. PLoS One. 2017;12(1):e0169613. doi: 10.1371/journal.pone.0169613 
12. Henwood T, Hetherington S, Purss M, Rouse K, Morrow J, Smith M. Active@home: investigating the value of a home care worker-led exercise program for older adults with complex care needs. J Aging Phys Act. 2019;27(2):284-9. doi: 10.1123/japa.2017-0443

13. Kono A, Kanaya Y, Fujita T, Tsumura C, Kondo T, Kushiyama K, et al. Effects of a preventive home visit program in ambulatory frail older people: a randomized controlled trial. J Gerontol A Biol Sci Med Sci. 2012;67(3):302-9. doi: 10.1093/gerona/glr176

14. Markle-Reid M, Browne G, Gafni A. Nurse-led health promotion interventions improve quality of life in frail older home care clients: lessons learned from three randomized trials in Ontario, Canada. J Eval Clin Pract. 2013; 19(1):118-31. doi: 10.1111/j.1365-2753.2011.01782.x

15. Muramatsu N, Yin L, Berbaum ML, Marquez DX, Jurivich DA, Zanoni JP, et al. Promoting seniors' health with home care aides: a pilot. Gerontol. 2018;58(4):779-88. doi: 10.1093/geront/gnx101

16. Watanabe $\mathrm{Y}$, Yamada $\mathrm{Y}$, Yokoyama $\mathrm{K}$, Yoshida T, Yoshinaka $\mathrm{Y}$, Yoshimoto $\mathrm{M}$, et al. Comprehensive geriatric intervention program with and without weekly class-style exercise: research protocol of a cluster randomized controlled trial in Kyoto-Kameoka Study. Clin Interv Aging. 2018;13:1019-33. doi: 10.2147/CIA.S151427

17. Granbom M, Kristensson J, Sandberg M. Effects on leisure activities and social participation of a case management intervention for frail older people living at home: a randomised controlled trial. Health Soc Care Community. 2017;25(4):1416-29. doi: 10.1111/hsc.12442

18. Barrios MDM, Pardo LHS, Ceballo GC. Fragilidad en el adulto mayor. Intervención educativa sobre los cuidados en el anciano. MediCiego [Internet]. 2010 [cited 2020 Feb 15];16(4). Available from: http://www.revmediciego.sld.cu/index.php/mediciego/article/view/1235/1362

19. Félix Neto F. Psicologia Social (Volume II). Lisboa: Universidade Aberta; 2000. 744 p.

20. Vries OJ, Peeters GM, Elders PJ, Muller M, Knol DL, Danner SA, et al. Multifactorial intervention to reduce falls in older people at high risk of recurrent falls: a randomized controlled trial. Arch Intern Med. 2010;170(13):1110-7. doi: 10.1001/archinternmed.2010.169

21. Instituto Nacional de Estatística INE. Lisboa: Portal do Instituto Nacional de Estatística[Internet].; 2019 [cited 2020 Jan 25 ]. Available from: http://www.ine.pt/

22. Direção-Geral da Saúde (PT). Direção de Serviços de Informação e Análise. A Saúde dos Portugueses. Lisboa; 2016. 177 p.

23. Fonseca MGUP, Firmo JOA, Loyola Filho Al, Uchôa E. Papel da autonomia na auto-avaliação da saúde do idoso. Rev Saúde Pública. 2010;44:159-65. doi:10.1590/S0034-89102010000100017

24. Organização Mundial de Saúde (OMS). Relatório Mundial de Envelhecimento e Saúde. [Internet]. Suíça: World Health Organization; 2015 [cited 2020 Jan 15]. 28 p. Available from: https://apps.who.int/iris/bitstream/handle/10665/186468/WHO_FWC_ALC_15.01_por.pdf;jsessioni $\mathrm{d}=46 \mathrm{BD} 986 \mathrm{C} 56534 \mathrm{D0B7CDBD08FC8B5ED33}$ ? sequence $=6$

25. Hall T. Management of persistent pain in older people. J Pharm Pract Res. Março de 2016;46(1):60- 7. doi: 10.1002/jppr.1194

26. Santos S, Figueiredo D. Preditores do medo de cair em idosos portugueses na comunidade: um estudo exploratório. Cienc Saude Colet. 2019;24(1):77-86. doi:10.1590/1413-81232018241.29932016

27. Vieira ER, Palmer RC, Chaves PH. Prevention of falls in older people living in the community. BMJ. 2016;353:i1419. doi: 10.1136/bmj.i1419

28. Swift CG, Iliffe S. Assessment and prevention of falls in older people--concise guidance. Clin Med. 2014;14(6):658-62. doi: 10.7861/ clinmedicine

29. Borel L, Alescio-Lautier B. Posture and cognition in the elderly: interaction and contribution to the rehabilitation strategies. Neurophysiol Clin. 2014;44(1):95-107. doi: 10.1016/j.neucli.2013.10.129

30. Santos ML, Borges GF. Exercício físico no tratamento e prevenção de idosos com osteoporose: uma revisão sistemática. Fisioter Mov. 2010;23:289-99. doi: 10.1590/S0103-51502010000200012

31. European Commission. Special Eurobarometer 472. Sport and Physical Activity[Internet]. Brussels, Belgium; 2018. [cited 2020 Feb 20]. 133 p. Available from: https://op.europa.eu/en/publication-detail/-/publication/9a69f642-fcf6-11e8-a96d-01aa75ed71a1/language-en/ format-PDF/source-82747397

32. Carvalho J. Pode o exercício físico ser um bom medicamento para o envelhecimento saudável? Acta Farm Port[Internet]. 2014 [cited 2020 Feb 20];3(2):125-33. Available from: http://www.actafarmaceuticaportuguesa.com/index.php/afp/article/view/52/87

33. Krug R, Lopes M, Mazo G. Barreiras e facilitadores para a prática da atividade física de longevas inativas fisicamente. Rev Bras Med Esporte. 2015;21(1):57-64. doi: 10.1590/1517-86922015210101673

34. Rico-Uribe LA, Caballero FF, Martin-Maria N, Cabello M, Ayuso-Mateos JL, Miret M. Association of loneliness with all-cause mortality: a metaanalysis. PLoS One. 2018;13(1):e0190033. doi: 10.1371/journal.pone.0190033

35. Faísca LR, Afonso RM, Pereira H, Patto MAV. Solidão e sintomatologia depressiva na velhice. Análise Psicológica. 2019; 37:209-22. doi: 10.14417/ap.1549

36. Azeredo Z, Barbeiro AP. O Idoso fragilizado no domicílio. Hospitalidade. 2015; 49 (307):36-9.

37. Rocha-Vieira C, Oliveira G, Couto L, Santos P. Impact of loneliness in the elderly in health care: a cross-sectional study in an urban region of Portugal. Fam Med Prim Care Rev. 2019;21:138-43. doi: 10.5114/fmpcr.2019.84550 